\title{
Intragastric Balloon: A Large Brazilian Multicentric Study Over 10,000 Cases and 20 Years of Experience
}

\author{
${ }^{1}$ Endoscopist Surgeon, Federal University of Minas Gerais, Brazil \\ ${ }^{2}$ Medical in Sander Medical Center, Brazil \\ ${ }^{3}$ General surgeon, Member of the Brazilian Society of Bariatric and Metabolic Surgery, Brazil \\ ${ }^{4}$ Clinical Director of SCARPARO, Clinic Scopia Day Hospital, Brazil \\ ${ }^{5}$ Positivo University, Surgeon and Endoscopist of Vita Batel Hospital in Curitiba, Brazil \\ ${ }^{6}$ Department of Surgery, Florida International University, Brazil \\ ${ }^{7}$ Faculty of Medicine of ABC, EndoVitta Institute Bariatric Endoscopist, Brazil \\ ${ }^{8}$ Digestive and Endoscopic Surgeon, Brazil \\ ${ }^{9}$ General Director of the Marchesini Clinic, Federal University of Paraná, Brazil \\ ${ }^{10} A B C$ Medical School, Doctor of Medicine, Brazil \\ ${ }^{11}$ Nutritionist at SCARPARO Clinic Scopia Day Hospital, Brazil \\ ${ }^{12}$ Medical School at Universidade Federal de Minas Gerais, Brazil
}

Bruno Queiroz Sander ${ }^{1 *}$, Marina Queiroz Sander², Dyker Santos Paiva ${ }^{3}$, Jimi Izaques Biffi Scarparo ${ }^{4}$, Giorgio Alfredo Pedroso Baretta ${ }^{5}$, Manoel Galvao Neto ${ }^{6}$, Eduardo Grecco ${ }^{7}$, Joao Antonio Schemberk Jr ${ }^{8}$, Joao Caetano Dallegrave Marchesini ${ }^{9}$, Thiago Ferreira de Souza ${ }^{10}$, Gabriel Caio Nunes ${ }^{11}$ and Luiz Ronaldo Alberti ${ }^{12}$

Submission: December 01, 2018; Published: February 13, 2019

"Corresponding author: Bruno Queiroz Sander, Endoscopist Surgeon, Federal University of Minas Gerais, Sander Medical Center, Av. Bernardo Monteiro, 1265 - Funcionários, Belo Horizonte - MG, 30150-285, Brasil

\begin{abstract}
Introduction: Obesity is a global disease and its management includes pharmacological therapy, non-absorptive surgery and intragastric balloon (IGB). The IGB has been used for more than 20 years in Brazil as an endoscopic method to aid in weight loss. Thus, the objective of this work was to describe the results of this procedure in IGB in Brazil.

Methods: This prospective study had a total of 10,255 patients submitted to IGB between 1997 and 2017. Patients with IGB filled with a fluid volume of between 620 and $700 \mathrm{ml}$, and a minimum initial BMI of $27 \mathrm{~kg} / \mathrm{m} 2$ were inserted non-study. The maximum follow-up time was nine months.
\end{abstract}

Results: This is a specific motion (31.1 years), mostly women (78\%). The mean BMI weight was: $33.42 \pm 6.62 \mathrm{~kg} / \mathrm{m}^{2}$, mean final BMI: 27.16 $\pm 8.42 \mathrm{~kg} / \mathrm{m}^{2}, \mathrm{p}<0.01$. The incidence of complications with IGB was $0.03 \%(\mathrm{n}=3)$ : gastric perforation. A total of $5.2 \%$ of the patients followed up for 18 months after a withdrawal of the IGB was submitted to bariatric surgery.

Conclusion: IGB is a safe and effective technique for weight loss, with complication rates. With the assistance of a multidisciplinary team, the results were satisfactory.

Keywords: Intragastric balloon; Obesity; Weight Loss; Complication

\section{Introduction}

Obesity is a persistent health problem in many lives, making it a challenge in medicine with a large concentration of studies. That is, it should be a great part of the metabolic repercussions and contraceptive outcomes with this comorbidity, with the increase rate of morbimortality rates with repercussions on the impact indices on patients' quality of life and also on the economy [1-4].

The obesity, which has many types of treatment, that may appear listed in set, depending of each case. Among the treatments 
found there are changes in patients' lifestyle, minimally invasive treatments and even different types of surgeries. The minimally invasive treatments for obesity, an intragastric (IGB) treatment technique, has been shown to be a promising procedure, since there are several projects with good results with significant weight and low complications. This is relevant a vapor note the high rates of failure of riots and the style of life, in addition to the admittedly known invasive treatments [5-8].

Thus, the objective of this study was to analyze the results of the six specialized centers in the treatment of obesity, using the minimally invasive procedures of the IGB, describing the clinical outcomes and their complications.

\section{Material and Methods}

This work was approved by the Research Ethics Committee under the CAAE protocol: 42995915.4.0000.5132. Seven centers specialized in the treatment of obesity, with wide experience in IGB participated in this study. For the standardization of the data, a model of filling of the data was elaborated in the Excel program, that after compiling all the data, these were sent for statistical analysis. All patients submitted to the IGB procedure between January and 1997 to December 2017 participated in this study. Among the inclusion criteria are: A liquid filled IGB with a volume between 620 to $700 \mathrm{ml}$ and patients with a minimum BMI of $27 \mathrm{~kg} / \mathrm{m}^{2}$.

Statistical analysis was performed using SPSS-IBM software (version 13.0). All data analyzed according to their distribution of normality. Statistical analysis was performed according to sex and degree of excess weight (overweight and grade I, II and III). Data were analyzed using Student t-test, and Tukey post-test. The level of significance was set at $\mathrm{p}<0.05$.

\section{Results \& Discussion}

In the period determined by the study, 10255 procedures were performed. Of this total of procedures, $4.8 \%(n=492)$ were excluded from the analysis of clinical outcomes of weight loss due to early withdrawal of IGB (Table 1). However, therapeutic failure of this study was lower than that observed in the study by Neto et al. [9]. Analysis of this group of excluded patients showed that $94 \%$ of them did not undergo a psychological evaluation before the procedure and $88 \%$ did not perform nutritional monitoring during the use of the IGB. This data reveals once again the importance of a multidisciplinary team in the treatment and follow-up of patients with IGB. Not just during, since treatment is temporary, and the multidisciplinary team builds long-term behavioral changes that will lessen the chances of regaining weight after IGB withdrawal.

Table 1: Reason of exclusion of study.

\begin{tabular}{|c|c|}
\hline Reason of exclusion & \% \\
\hline Early IGB removal & $2,2(\mathrm{n}=226)$ \\
\hline Absence of weight loss & $1,13(\mathrm{n}=116)$ \\
\hline Weight gain & $0,41(\mathrm{n}=42)$ \\
\hline Incomplete data & $1,05(\mathrm{n}=108)$ \\
\hline
\end{tabular}

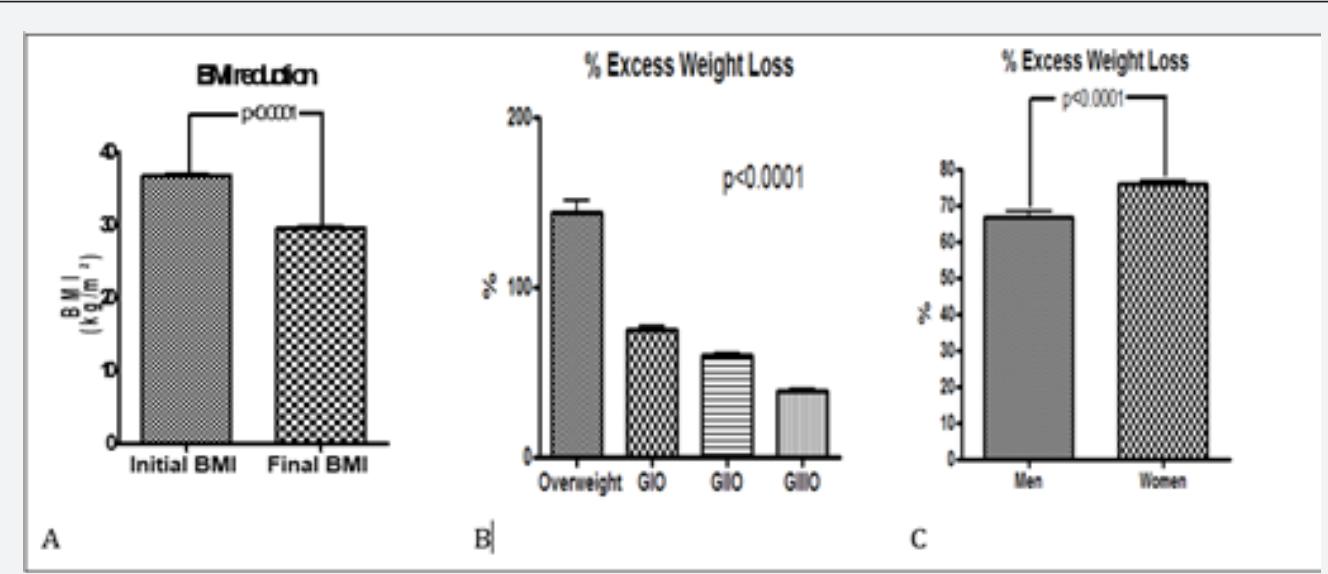

Figure 1: Outcomes by success of treatment.

Legend: A: outcome BMI reduction (Mean BMI reduction: $6.26 \pm 3.49 \mathrm{~kg} / \mathrm{m}^{2}$ ); B: \% Excess weight loss by BMI score; C: \%Excess weight loss by gender.

The percentage PEP was higher in the overweight group (129.92\% PEP), followed by obese I (73.64\%), II (57.85\%) and III (41.33\%) sequentially. A total of 5.2\% (66/1 268) of the patients followed up for 18 months after withdrawal of the IGB was submitted to bariatric surgery. Among the observed complications were spontaneous hyperinflation in $0.99 \%$ ( $\mathrm{n}=$ 101) and spontaneous deflation or leakage in $0.82 \%(n=84)$. Kim et al. [16] in their review observed that spontaneous deflation occurs in approximately $6 \%$ of patients, a rate much higher than that observed in the present study. With increasing advances in biomaterials, the newer balloons have a greater gastric capacity and are filled with saline, producing fewer adverse effects, which may explain in part the low deflation of this study.

The epidemiological profile is a young population with a mean age of 31.1 years, mostly women $(78 \%, n=7,615)$. This 
profile is similar to that described in several papers [5,6,10-15]. Clinical outcomes related to therapeutic success (Figure 1), show that there was a significant weight loss, with significantly lower final BMI $\left(27.16 \pm 8.42 \mathrm{~kg} / \mathrm{m}^{2}\right.$; variation: $\left.15.71-34\right)$ than the baseline BMI ( $33.42 \pm 6.62 \mathrm{~kg} / \mathrm{m}^{2}$, range: 27 to 79.35$)$. The mean weight loss was $-16.98 \mathrm{~kg}(+/-16.8 \mathrm{~kg})$. The primary endpoint of therapeutic success in our study was a mean reduction of BMI of $6.26 \mathrm{~kg} / \mathrm{m}^{2}$ and an average weight loss of $16 \mathrm{~kg}$, data similar to that found by Neto et al. [9].

The incidence of complications that did not lead to removal was $6.65 \%(n=682)$. Other complications occurred as fungal contamination in $7.9 \%(n=810)$; Wernick Korsakoff syndrome $0.01 \%(n=2)$, gestation during the implant period was $1.2 \%$ (n $=123$ ) and the Dieulafoy lesion $0.01 \%(n=1)$. The incidence of complications with IGB removal was $0.03 \%(n=3)$ : gastric perforation. Não houve nenhum caso de mortalidade nesse estudo.

\section{Conclusion}

The observed data corroborate the international literature [5-8,12-19], showing that the technique is safe, effective and with low complication rates. The multidisciplinary team is important in conducting treatment for therapeutic success. Further study evaluating the variables involved in the complications is necessary in order to provide a more adequate selection of whistleblowers to this procedure.

\section{References}

1. Chooi YC, Ding C, Magkos F (2018) The epidemiology of obesity Metabolism (18): 30194.

2. Inoue Y, Qin B, Poti J, Sokol R, Gordon-Larsen P (2018) Epidemiology of Obesity in Adults: Latest Trends. Current obesity reports 7(4): 276288.

3. Konnopka A, Dobroschke A, Lehnert T, Konig HH (2018) The Costs of Overweight and Obesity: a Systematic Review. Gesundheitswesen 80(5): 471-481.

4. Matta J, Carette C, Rives Lange C, Czernichow S (2018) French and worldwide epidemiology of obesity. Presse medicale 47(5): 434-438.

5. Ashrafian H, Monnich M, Braby TS, Smellie J, Bonanomi G, et al. (2018) Intragastric balloon outcomes in super-obesity: a 16-year city center hospital series. Surgery for obesity and related diseases: official journal of the American Society for Bariatric Surgery 14(11): 1691-1699.

6. Ribeiro da Silva J, Proenca L, Rodrigues A, Pinho R, Ponte A, et al. (2018) Intragastric Balloon for Obesity Treatment: Safety, Tolerance, and Efficacy. GE Portuguese journal of gastroenterology 25(5): 236-242.

7. Tate CM, Geliebter A (2018) Intragastric Balloon Treatment for Obesity: FDA Safety Updates. Advances in therapy 35(1): 1-4.

8. Velotti N, Bianco P, Bocchetti A, Milone M, Manzolillo D, et al. (2018) Acute complications following endoscopic intragastric balloon insertion for treatment of morbid obesity in elderly patients. A single center experience. Minerva chirurgica.

9. Neto MG, Silva LB, Grecco E, de Quadros LG, Teixeira A, et al. (2017) Brazilian Intragastric Balloon Consensus Statement (BIBC): practical guidelines based on experience of over 40,000 cases. Surg Obes Relat Dis 14(2): 151-159.

10. Sullivan S, Swain J, Woodman G (2018) Randomized sham-controlled trial of the 6-month swallowable gas-filled intragastric balloon system for weight loss. Surgery for obesity and related diseases: official journal of the American Society for Bariatric Surgery 14(12): 1876-1889.

11. Madeira E, Madeira M, Guedes EP, Mafort TT, Moreira RO, et al. (2018) Impact of Weight Loss With Intragastric Balloon on Bone Density and Microstructure in Obese Adults. J Clin Densitom (17): 30187-30197.

12. Tsaousi G, Grosomanidis V, Kotzampassi K (2017) Intragastric Balloon for Management of Severe Obesity: Letter to the Editor. Obes Surg 27(2): 476-477.

13. Tate CM, Geliebter A (2017) Intragastric Balloon Treatment for Obesity: Review of Recent Studies. Adv Ther 34(8): 1859-1875.

14. Abu Dayyeh BK (2017) Intragastric Balloons for Obesity Management. Gastroenterology \& hepatology 13(12): 737-739.

15. Al-Sabah S, Al-Ghareeb F, Ali DA, Al-Adwani A (2016) Efficacy of intragastric balloon for the management of obesity: experience from Kuwait. Surgical endoscopy 30(2): 424-429.

16. Kim SH, Chun HJ, Choi HS, Kim ES, Keum B, et al. (2016) Current status of intragastric balloon for obesity treatment. World journal of gastroenterology 22(24): 5495-5504.

17. Cote GA (2016) The Return of Intragastric Balloons for Obesity Management. Gastroenterology 150(3): 771-772.

18. Fittipaldi-Fernandez RJ, Guedes MR, Galvao Neto MP, Klein M, Diestel CF (2017) Efficacy of Intragastric Balloon Treatment for Adolescent Obesity. Obesity surgery 27(10): 2546-2551.

19. Nguyen V, Li J, Gan J (2017) Outcomes following Serial Intragastric Balloon Therapy for Obesity and Nonalcoholic Fatty Liver Disease in a Single Centre. Canadian journal of gastroenterology \& hepatology 4697194. 

(C) Commons Attribution 4.0 License DOI: $10.19080 / A R G H .2019 .12 .555839$
Your next submission with JuniperPublishers will reach you the below assets

- Quality Editorial service

- Swift Peer Review

- Reprints availability

- E-prints Service

- Manuscript Podcast for convenient understanding

- Global attainment for your research

- Manuscript accessibility in different formats

( Pdf, E-pub, Full Text, audio)

- Unceasing customer service

Track the below URL for one-step submission https://juniperpublishers.com/online-submission.php 